\title{
Social media adoption in higher education: a case study involving IT/IS students
}

\section{Kerstin Siakas*}

Department of Informatics, Alexander Technological Educational Institute of Thessaloniki, P.O. Box 141,

Thessaloniki 57400, Greece

Email: siaka@it.teithe.gr

*Corresponding author

\section{Pekka Makkonen}

Faculty of Information Technology, University of Jyväskylä, P.O. Box 35, Jyväskylä 40014, Finland Email: pmakkone@jyu.fi

\section{Errikos Siakas}

Aristotle University of Thessaloniki,

IT Centre,

University Campus,

Thessaloniki 54124, Greece

Email: esiakas@it.auth.gr

\section{Elli Georgiadou and Harjinder Rahanu}

Faculty of Science and Technology, Middlesex University London,

The Burroughs, London NW4 4BT, UK

Email: e.georgiadou@mdx.ac.uk Email: h.rahanu@mdx.ac.uk

\begin{abstract}
This paper discusses the adoption and use of social media in Higher Education (HE). The aim of the research reported in this paper was to identify the main factors and problem areas in the adoption and use of social media in HE. Our study included a survey involving students of Information Technology and Information Systems in Greece and in Finland. In order to verify the findings from the survey, a follow-up survey was also undertaken. The unified technology adoption approach was identified to be a suitable underlying theory for this study. The analysis of viewpoints of students was needed in order to understand converging and diverging viewpoints. The results showed that infrastructure is the most important issue in the planning of learning/teaching
\end{abstract}


activities based on social media, followed by the role of social influence. Based on the analysis, guidelines for planning social-media-based learning activities are proposed. Indications of further work complete the paper.

Keywords: case study; IS students; IT students; learning; social media; social media adoption; social media in higher education; social networking; social network sites; teaching.

Reference to this paper should be made as follows: Siakas, K., Makkonen, P., Siakas, E., Georgiadou, E. and Rahanu, H. (2017) 'Social media adoption in higher education: a case study involving IT/IS students', Int. J. Social Media and Interactive Learning Environments, Vol. 5, No. 1, pp.62-78.

Biographical notes: Kerstin Siakas is a Professor at the Department of Informatics at ATEI of Thessaloniki, Greece. She is engaged in research in Multidisciplinary Approaches of Software Engineering. She has a particular interest in the social, cultural and political approaches and their effect on society, as well as on the subsequent challenges for managers, educators and governments.

Pekka Makkonen has been an ICT/IS professional since 1985. Internationally, he has worked as a Teacher in various European universities as the head of ICT School in Afghanistan, a Teacher Trainer in Saudi Arabia, a Training Expert in South Sudan and an e-learning expert in Tanzania. He has developed e-learning and created student-centred/driven approaches for collaborative learning on the internet. He has also worked intensively with local companies in Finland to create working-life-oriented ICT/IS education.

Errikos Siakas holds a BSc in Software Engineering from the Department of Informatics at ATEI of Thessaloniki and MSc in Networks Communications Systems Architectures from Aristotle University of Thessaloniki, Greece. Currently, he works as an IT Specialist at the IT Department of Aristotle University. He is an ECQA certified social media Networker and Valorisation expert.

Elli Georgiadou is a Fellow of the BCS, a Quality Management consultant and a Visiting Academic \& EU Projects Advisor (having managed several large European Research and Knowledge Transfer projects) at the Faculty of Engineering and Information Sciences, Middlesex University, London, UK. She has over 30 years of teaching in Higher Education as a Principal Lecturer and has published widely on Software Quality Engineering, and Education.

Harjinder Rahanu is a Senior Lecturer in Business Information Systems from the Faculty of Science and Technology at Middlesex University London. He holds a $\mathrm{PhD}$ in ethics and artificial intelligence. His primary teaching is focused on object-oriented analysis and design. His areas of research include computer ethics, information literacy and technology supported learning.

This paper is a revised and expanded version of a paper entitled 'Adoption of social media in the teaching of IS/ICT: Comparing students to faculty members', presented at the 27th annual conference of the Society for Information Technology and Teacher Education, March 2016, (Site2016), Savannah, Georgia, US. 


\section{Introduction}

Communication, collaboration and sharing are the foundation of social media. The term social media is interchangeable with the terms Web 2.0 and social software (Dabbagh and Reo, 2011). In the last 5 years, social media platforms (SMPs) have been established both in academic and public use. SMPs mainly include internet and mobile-based technologies used to turn communication into interactive dialogue among individuals, communities and organisations. They enable users to create, engage and share new or existing content, in digital environments via multi-way communication denoting multiple paths, channels or configurations (Davis et al., 2012). SMPs consist of factors that establish virtual social spaces encouraging communication and interaction.

In recent years, technology-enhanced learning has become a fundamental part of higher education (HE) (Siakas et al., 2011). Rapid advances in information and communication technologies (ICTs) have initiated fast and easy access to new electronic learning environments. In particular, SMPs have become an integral part of modern society. They have completely changed the way we communicate, share and co-create information. Social networking is accomplished through a bottom-up approach and crowd-sourcing (Siakas et al., 2014). Engagement in SMPs usually means that stakeholders become active participants to a higher degree. This is partly due to the fact that learning becomes fun and is akin to leisure activities that these young people participate in, as opposed to remaining as spectators. The objective of motivating students to actively participate in their learning process has reached a higher level in comparison to tradition settings since more participants (students) engage in all forms of social discourse by multi-way communication and action.

The expression, social networking sites (SNSs), is used as an umbrella term for all social media and computer-mediated communication, including but not limited to Facebook, Twitter and LinkedIn. SNSs offer a new bottom-up type of channel among internet users for collaboration, communication, creativity and socialising with each other (Abedin, 2016; Mooney, 2009). A bottom-up approach works from the grassroots - from a large number of people working together, usually causing a decision to arise from their joint involvement (Dubois, 2002). In our study, the bottom-up approach refers to students who are expected to actively collaborate for increased learning. Despite the fact that most SNSs appear to be similar regarding their characteristics of co-creation and knowledge sharing, many of them are different in terms of their purpose and the types of users they attract. Now, Wikis, Blogs and social networking are as important to learning as the lecture theatre and campus infrastructure in a traditional University campus (Daniel, 2012). They take the form of discussions via fora, blogs and microblogging (mainly Twitter). When using SNSs in HE, learners are expected to take initiative and to play an active role in their learning process.

Cachia (2008, p.7) argued that most users of SNSs use them to 'social search' people they have met offline and to stay in touch and consolidate relations with core friends'. Others extend their networks, using their online visibility to augment professional opportunities, amplify weak ties and to exploit their few minutes of fame.

Figure 1 depicts that SNSs are characterised by ease of use and bottom-up activities. People use SNSs to interact with each other within a common information space and to participate in diverse interactive and social activities, such as posting content, sharing pictures and videos, tagging and organising events (Pallis et al., 2011). Due to the fact that these technologies are embedded in, and are integral to, the everyday lives of young 
people, they are likely to increase the engagement of students in an online learning community (educationally, they can have encouraging academic outcomes (Deng and Tavares, 2013; Graham, 2014; Hrastinsk and Aghaee, 2012; Junco, 2011; Junco et al., 2013; Oradini and Saunders, 2008; Welch and Bonnan-White, 2012). The results of different studies seem to indicate that for social media to achieve its full potential, students need to be inculcated, nurtured and encouraged to engage with this form of learning (Graham, 2014). In particular, in online courses, achieving student engagement may be more important than it is in on-campus courses because online students have fewer ways to be engaged with the institution and probably also greater demands on their time and attention (Meyer, 2014).

Figure 1 Characteristics of SNSs (see online version for colours)

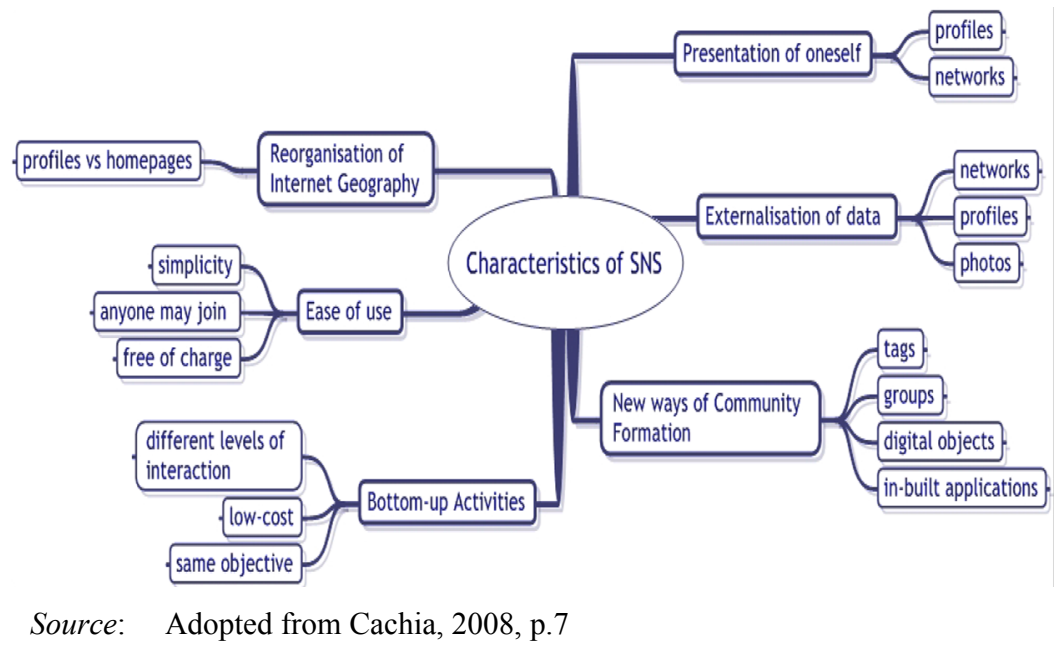

Figure 2 Basic theoretical model on user intention and actual use of social media

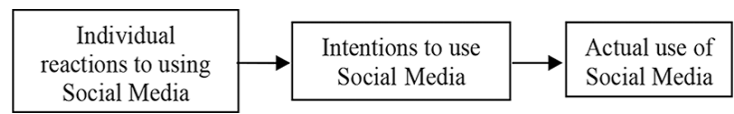

Source: Adopted from Venkatesh et al. (2003), p.427

The use of SNSs in HE is rapidly expanding. Social networking in HE has the potential to enable new pedagogic, student-centred ways through their bottom-up approach for supporting knowledge activities that harness collective intelligence as opposed to hierarchical teacher-centred approaches (Georgiadou et al., 2014).

The objectives of universities are to ensure that all their students are in a position to make educational progress. Progress requires that the students are helped to be successful in their tasks. Educators, along with millions of other online adults, are joining social networks and adopting a variety of content-sharing tools for personal, professional and classroom use.

The use of social media in HE is a recent trend for increasing the motivation of the students and for enhancing their education. Social media and digital literacy are high among young people. The use of social media in HE is likely to increase the means to persuade and influence, and the ability to reach a wider audience. Students are no longer 
just consumers of information and teaching material, but potential active content creators and distributors.

Seaman and Tinti-Kane (2013) reported in their results from a survey including 7969 responses that in total $59 \%$ of faculty members consider that better learning outcomes can be achieved using social media. At the same time, however, $56 \%$ of faculty members consider that these technologies can be distracting in HE. Because of this disharmony concerning the role of social media in HE, we should comprehend that social media tools are technology tools and applications similar to any other business or educational software (Makkonen et al., 2016).

These issues and particularly the issue of social media adoption in HE require investigation. Innovative technologies (infrastructure as well as applications) are likely to follow the same cycle of diffusion as other technology innovations and their adoption. New generations of students are likely to belong to the category of early adopters as defined by Rogers (2003) in his innovation adoption theory and illustrated by among others Keesee and Shephard (2011) as self-adopters.

This paper considers the opinion of HE students from IT/IS departments at the University of Jyväskylä, Finland and at the Alexander Technological Educational Institute of Thessaloniki, Greece regarding the adoption and use of social media in HE. The paper presents an analysis of responses to a survey which identifies and ranks important factors affecting the adoption and use of social media in HE. Also guidelines for planning socialmedia-based learning activities are proposed.

\section{Social media in HE and IS/ICT education}

Seaman and Tinti-Kane (2013) have studied the use of social media in teaching and learning. They assert that over $70 \%$ of faculty members use social media at least once a month or more and $41 \%$ use social media in their teaching activities (Seaman and Tinti-Kane, 2013). Active use of social media in the classroom, which has been primarily passive or consumptive in the past (e.g. in the form of watching an online video), is on the rise. The positive impact on learning communities is significant based on the volume of social media use. In particular, the use of blogs and wikis has affected teaching activities significantly. On the other hand, podcasts, LinkedIn, Facebook and Twitter are less significant (Seaman and Tinti-Kane, 2013, pp.7-9). Another aspect that requires investigation is the quality of learning. Lau et al. (2014), for example, show the significantly positive effects of social media used on the quality of learning in terms of learning performance and motivation.

The real benefits of social media used in HE are based on understanding learning theories. Social constructivist theory explains how and why social contacts and interaction are vital for learning (Vygotsky, 1978). Connectivism as a learning theory clarifies the prevailing technical point of view in which human beings are more connected using different media and social media (Siemens, 2005). Technology, in general, and social media in particular, create a learning experience that makes students more interested in the learning process. Numerous online courses now include social networking in order to augment collaboration and learner interaction. In many learning management systems, social networking is assembled into units through embedded html scripts. Social media tools facilitate more effective and engaging collaboration with teachers and peers. Today, pedagogical tendencies, such as learning to learn, seem to be 
considered to have greater impact on future experiences than the construction of domainspecific knowledge itself (Grodecka et al., 2009).

The use of SNSs by students is more dominant outside the university, during leisure time. Networked students increasingly use Facebook, Google+, Instagram, Twitter, Skype, Viber and YouTube among other social media tools to communicate. The Net Generation students have grown up with the technology, computers, video games and the internet. Because of this, they share common experiences and a culture that is defined by certain attributes and is related to how they interact with ICTs, information itself and other people. New learning experiences need to adapt to the new generation of learners by supporting a more collaborative, social, user-generated content view of the world.

New SNSs emerge every day, including new opportunities and new challenges. Teachers are increasingly using social media tools to support teaching and learning in traditional classroom environments in order to provide new opportunities for enriching existing curriculum through authentic, creative, flexible and non-linear learning experiences. According to Deng and Yuen (2011), participants who use social media build an active audience engaged in collaborative content creation. This aligns with the constructivist learning paradigm, which views learners as active creators of knowledge, and learning as a social process. Using social media implies that both students and teachers become more active and involved on a personal level (Faraon et al., 2011). Scholars have also identified increased academic success as a result of social media use (Grover and Stewart, 2010; Rodrigues, 2011). Students have enumerated the usefulness of SNS as an e-learning tool that has led to improved learning success. These include (Dabbagh and Kitsantas, 2012) the following:

- Downloading teaching materials as images on SNSs in order to gain better understanding assignments.

- Exchanging information and experiences with teachers and peers.

- Forming specialised groups related to each topic in a syllabus.

- Creating dedicated pages facilitating access to uploaded learning materials related to specific topics that students can read while using SNSs.

- Using a forum where students can clear doubts concerning learning and completion of assessments, including online trouble shooting for practical projects.

Proponents of the use of SNSs as a conduit for teaching suggest that a core reason for social media's ability to lead to improved academic success in HE is its enabling power to allow for the creation of personal learning environments that empower students with a sense of personal agency in the learning process (Minocha and Kerawalla, 2011).

\section{Technology adoption theories}

A lot of theories deal with technology adoption. Diffusion theories of technology can partly explain the drivers of social media adoption. The first diffusion theory for technology innovations includes innovation diffusion theory (Rogers, 2003). It emerged in the 1960s and comprehends the adoption of an innovation as a social process. Another explanation for technology adoption is the theory of reasoned action (TRA). TRA has its background in developing technology diffusion and adoption theories (Ajzen and 
Fishbein, 1980). According to this model, a person's activity is the result of their attitude and personal norms. In turn, the attitude of a person is based on values and beliefs. The personal norms are based on motivation to act according to accepted norms. In order to understand the factors and the processes affecting intention of people to use and adopt SNSs, it is necessary to understand the underlying theory. Theoretical models on user acceptance of Information Technology (e.g. internet) articulate intention to use and actual use as the main dependent variables (Venkatesh et al., 2003).

Intention to use IT is a valid predictor of behaviour regarding future use and adoption of technology.

There are several models that explain behavioural viewpoints of consumers regarding new technology and intentions to use that technology, as for example:

- $\quad$ TRA (Fishbein and Ajzen, 1975).

- Attitude model of Fishbein, which consists of three sub-models: the attitude towards the object model, attitude towards the behaviour model and the theory of reasoned action (see for example Onkvisit and Shaw, 1994 or Schiffman and Kanuk, 1994).

- $\quad$ Technology acceptance model (TAM) (Davis, 1989).

- $\quad$ Theory of planned behaviour (Ajzen, 1991).

- Innovation diffusion theory (Rogers, 2003).

- Combination of models (Nysveen et al., 2005).

The TAM (Davis, 1989; Davis et al. 1989) discusses practical technology use issues. TAM emphasises usefulness in addition to user friendliness. Mathieson et al. (2001), for example, emphasise that the TAM model should be expanded by adding available resources. Similarly, Venkatesh and Davis (2000) expanded TAM further to include the concept of perceived usefulness. This model is called TAM2. Subsequently, the unified theory of acceptance and use of technology (UTAUT) were presented by Davis et al. $(1989 ; 2012)$. The UTAUT deals with the social aspect which is a notable aspect in the emergence of social media in various areas including education. The major intentional factors of the UTAUT theory include the following (Venkatesh, et al., 2003):

- performance expectancy

- $\quad$ effort expectancy

- $\quad$ social influence

- facilitating conditions.

Other factors that influence intention to use and actual use are:

- gender

- age

- experience

- voluntariness of use. 


\section{Our studies}

The objective of our study was to explore what is important to the adoption of social media in HE based on both the views of students and teaching staff (Instructors).

The research question considered which factors influence the adoption of social media in HE. In order to investigate this, we carried out a study in the academic year 2014-2015 including a structured survey towards graduate and postgraduate students of two IT/IS faculties in one university in Greece and one in Finland, as well as IT/IS faculty members with teaching responsibilities (Makkonen et al., 2016). The fact that all respondents were either students or teaching staff from the IS/IT field ensures a degree of homogeneity and familiarity with new technologies.

In this paper, we concentrate on the results from student responses so that instructors can find out where to put emphasis when creating social-media-based learning activities. Content developers need to especially be aware of what tools make sense in a current educational setting.

We selected the UTAUT approach for this study (Makkonen et al., 2016) because it covers the various drivers for technology adoption. In this paper, we concentrate on social media adoption amongst IT/IS students.

The items (or social media services) for the survey were selected from Seaman and Tinti-Kane's (2013) reports. Thus, some newer services such as Instagram are not included in the study directly. We studied the items in the light of UTAUT.

In order to verify the findings, we also carried out a follow-up study in 2014-2015 in the same IT/IS department in Greece. The target group consisted of both undergraduate and postgraduate students including those who also had responded to the main questionnaire.

This paper presents only results from the students. A comparison between results of students and faculty members is presented in Makkonen et al. (2016).

The aim of the main study was to understand what teaching staff should concentrate on when creating social-media-based learning activities for their students. In this, it is important to know what promotes the use of social media and what impairs it.

Derived from the UTA, the major variables were as follows:

- gender

- age

- $\quad$ experience in the use of social media

- $\quad$ voluntary use social media

- $\quad$ infrastructure for using social media

- meaning of social influence

- $\quad$ ease of use of social media applications

- help (benefit) of social media in a task or a study.

A questionnaire including these main items concerning the adoption of social media was designed and distributed to IT/IS students and teaching staff in two universities in Finland and in Greece. In total, 71 Finnish students, 20 females and 51 males, with mean age 25 years (range: 19-57 years) and 101 Greek students, 22 females and 79 males, with mean 
age 23 years (age range: 18-52 years) completed the questionnaire. The respondents rated each item of social media adoption on a Likert scale of $1-5(1=$ not significant and 5 = significant).

In order to confirm the findings and further investigate the use of social media by students, a follow-up study including an electronic online questionnaire with 239 undergraduate respondents was undertaken in the spring semester of 2015 (Tsitsekidou, 2015 ) comprising $23.4 \%$ female and $76.6 \%$ male students. In total, $57.3 \%$ of the students were $20-25$ years old and $40.6 \%$ under 20 years old. No teaching staff were included in the follow-up study.

The aims of the follow-up study were to derive information that can lead to a better understanding of the issues for implementing social media in the education and learning processes.

Factors, such as time spent on social media, motivation of use, evaluation of application of social media regarding educational aspects and their learning processes, specification of concerns regarding social media use in education were investigated.

Furthermore, we examined the use of a Facebook group among 42 postgraduate students and measured the contribution of the Facebook group to the students' learning process by factors, such as students' engagement, students' motivation, students' collaborative learning and students' satisfaction. In addition, we examined any significant correlations between our variables. The postgraduate students that participated in this study were members of a Facebook group which had been created to support them in their postgraduate studies of the 'Web Intelligence' course. The Facebook group was created and managed by the students and was being used exclusively by them.

In total, 21 postgraduate students enrolled in 2014, aged from 25 to 40 years old, 6 females and 15 males. They were experienced Facebook users. In 2015, a total of 21 postgraduate students enrolled in 2015, aged from 20 to 45 years old, 3 females and 18 males, considered themselves as having medium Facebook experience. Both of the Facebook groups were used to facilitate the students' learning experience as well as to promote their communication and interaction in an online environment outside the classroom.

Table 1 outlines the research process and provides geographic and demographic information.

Table 1 The research process and demographics

\begin{tabular}{|c|c|c|c|}
\hline & Main study & Follow-up study & \\
\hline $\begin{array}{l}\text { Level of } \\
\text { students }\end{array}$ & $\begin{array}{l}\text { Graduate and } \\
\text { postgraduate students }\end{array}$ & Undergraduate students & Postgraduate students \\
\hline $\begin{array}{l}\text { Number of } \\
\text { students }\end{array}$ & $\begin{array}{l}71 \text { Finnish } \\
101 \text { Greek }\end{array}$ & 239 Greek & 42 Greek \\
\hline Aims of study & $\begin{array}{l}\text { To explore what is } \\
\text { important to the adoption } \\
\text { of social media in HE }\end{array}$ & $\begin{array}{l}\text { - To validate the } \\
\text { results of the main } \\
\text { study } \\
\text { - To further } \\
\text { investigate the use } \\
\text { of social media by } \\
\text { students }\end{array}$ & $\begin{array}{l}\text { - To examine the } \\
\text { use of a Facebook } \\
\text { group used by } \\
\text { students }\end{array}$ \\
\hline
\end{tabular}


Table 1 The research process and demographics (continued)

\begin{tabular}{|c|c|c|c|}
\hline & Main study & Follow-up study & \\
\hline $\begin{array}{l}\text { Research } \\
\text { question }\end{array}$ & $\begin{array}{l}\text { Which factors influence } \\
\text { the adoption of social } \\
\text { media in HE? }\end{array}$ & $\begin{array}{l}\text { What social media tools } \\
\text { have a positive impact } \\
\text { on students learning? }\end{array}$ & $\begin{array}{l}\text { How does a Facebook } \\
\text { group influence the } \\
\text { students' learning } \\
\text { process? }\end{array}$ \\
\hline $\begin{array}{l}\text { Research } \\
\text { factors }\end{array}$ & $\begin{array}{l}\text { Experience in the } \\
\text { use of social media } \\
\text { - } \quad \begin{array}{l}\text { Voluntary use of } \\
\text { social media }\end{array} \\
\text { - } \quad \begin{array}{l}\text { Infrastructure for } \\
\text { using social media }\end{array} \\
\text { - } \quad \begin{array}{l}\text { Meaning of social } \\
\text { influence }\end{array} \\
\text { - } \quad \begin{array}{l}\text { Ease of use of social } \\
\text { media applications }\end{array} \\
\text { Help (benefit) of } \\
\text { social media in a } \\
\text { task or a study }\end{array}$ & $\begin{array}{ll}\text { Students' } \\
\text { - } & \text { Time spent on } \\
\text { social media } \\
\text { - } & \text { Motivation of use } \\
\text { - } & \begin{array}{l}\text { Concerns } \\
\text { regarding social } \\
\text { media use in } \\
\text { education }\end{array} \\
\text { - } & \text { Viewpoint of } \\
\text { social media in } \\
\text { education } \\
\text { - Viewpoint of } \\
\text { social media } \\
\text { influence on } \\
\text { learning processes }\end{array}$ & $\begin{array}{l}\text { Students' } \\
\text { - } \quad \text { Engagement } \\
\text { - } \quad \text { Motivation } \\
\text { - } \quad \text { Collaborative } \\
\text { learning } \\
\text { - } \quad \begin{array}{l}\text { Satisfaction with } \\
\text { use of Facebook } \\
\text { group }\end{array}\end{array}$ \\
\hline
\end{tabular}

\section{Main findings of the two studies}

\subsection{Findings from the main survey involving 172 students}

Initial findings from the quantitative survey showed the importance of the different aspects of the UTAUT model when applied to the adoption of social media in HE (Makkonen et al., 2015).

The results showed that the first priority when planning to use social media in HE is the need to pay special attention to ICT infrastructure before implementing social media solutions. The second issue concerns the selection of the most suitable platforms in terms of usability. After this, an educator should discuss how e-learning on social media should be organised in order to support learners' development in their work and/or studies. We also found that the students consider the social influence highly important. This should be looked at while creating social-media-based learning activities. We must especially be aware what tools make sense in the current HE. In order to investigate what tools are suitable according to students in the same educational settings, a follow-up study was carried out aiming to increase the understanding of social media tools that students prefer in their leisure time and in their learning environment. In this way, we can create learning activities in which the students can experience contemporary learning with modern tools which they prefer. Using popular social media tools, students consider useful for their learning, it may motivate them in further steps of their studies.

When comparing male and female students, no significant difference was found except in the general experience in social media. Male students were more experienced than female students. Other studies have found similar results (Statistics, Finland, 2010). 
The follow-up study did not find any relationship between the gender of students and the activity reported by students regarding their use of Facebook (Tsitsekidou, 2015). Pearson's chi-square tests were used for both undergraduate and postgraduate students.

\subsection{Findings from the follow-up survey involving 239 students}

The follow-up study towards undergraduate students (Tsitsekidou, 2015) confirmed that $69.9 \%$ of the students believe that the use of social media in HE is important, and facilitates learning in a positive way. In particular, students consider that Facebook groups are useful as a collaborative learning tool. According to the students' statements, the first three benefits of using social media in learning are unconscious, namely, learning, knowledge sharing and organisational skills.

The social media tools that students use in their private lives were ranked according to their popularity. YouTube was ranked as the most popular by the students with $99 \%$, Facebook followed second with 93\% and Skype third with $75 \%$.

The three social media tools that are considered most important for learning by the undergraduate respondents are as follows:

1 YouTube comes first of social media tools with 94\% of the respondents rating it important for learning (18\% of the correspondents state that YouTube can have a little contribution to their learning process, $28 \%$ fair contribution, $29 \%$ big contribution, $19 \%$ very big contribution, whilst only $6 \%$ believe that YouTube is unsuitable for their educational needs).

2 Facebook comes second with $81 \%$ of the respondents considering that it contributes to their learning ( $40 \%$ of the students state that the contribution of Facebook is little, $25 \%$ fair, $10 \%$ big, $6 \%$ very big, whilst 19\% do not consider Facebook a suitable learning tool).

$3 B \log s$ are considered as an important social media tool in learning by $77 \%$ of the respondents $(17 \%$ of the students state that Blogs help them but a little, $28 \%$ that Blogs are fairly helpful, 10\% very helpful, $5 \%$ immensely helpful, whereas $40 \%$ do not support the idea of applying Blogs in their daily learning sources).

The percentages for perceived importance of social media use in HE are slightly lower than the actual use in private life reported by the respondents. The results show that YouTube and Facebook are both popular in students' leisure time, but also consider as the social media tools that provide the highest potential learning outcome.

Table 2 shows the rating by the undergraduate students of social media tools according to learning aspects.

Table 2 Learning aspects in different social media tools

\begin{tabular}{lcccccc}
\hline \multicolumn{6}{c}{ The three most important social media tools according to learning aspect } \\
\hline & Unconscious & Knowledge & Organisational & Team & Meeting & \\
& learning & sharing & skills & spirit & peers & Visibility \\
\hline 1 & Second life & Forums & Wikis/Google+ & Skype & Facebook & YouTube \\
2 & LinkedIn & Facebook & LinkedIn & Facebook & Skype & Instagram \\
3 & Instagram & Blogs & Blogs & LinkedIn & Twitter & LinkedIn \\
\hline
\end{tabular}


From Table 2, we conclude that YouTube, which was considered the most important social media tool for learning, has the highest ranking in visibility. Facebook that was considered as the second most important tool for learning has the highest ranking in meeting peers and the second highest in knowledge sharing and team spirit.

\subsection{Findings from the postgraduate study involving 42 postgraduate students}

The follow-up study examined which social media tools are considered helpful to their learning by students: Facebook was considered as the most important for sharing and generating tacit knowledge amongst each other because it is easy to use and familiar to students. This is in agreement to the findings by Ractham and Firpo (2011) who state that there is a great potential for informal learning environments where users utilise Facebook as a centralised space to communicate, collaborate and achieve complementary learning to the in-class material.

For each group of postgraduate students (enrolled 2014 and 2015), we calculated the average score of four constructs consisting of three parameters. The results are shown in Table 3. For example, the engagement is calculated according to numbers of hours spent weekly on the Facebook group, the rate of visiting frequency on group and the type of member activity within the group.

Table 3 Percentage of the students' average score for each construct

\begin{tabular}{lcc}
\hline & Group 2014 (\%) & Group 2015 (\%) \\
\hline Engagement & 54 & 41 \\
Motivation & 63 & 67 \\
Collaborative learning & 69 & 61 \\
Satisfaction & 59 & 58 \\
\hline
\end{tabular}

Table 3 shows that the contribution of the Facebook group to the students' learning process by factors, such as students' engagement, students' motivation, students' collaborative learning and students' satisfaction, is rather high.

Our study indicates that a Facebook group is an important tool for enhancing students' learning and can highly support the collaboration between them.

\section{Guidelines for planning social-media-based learning activities}

It was evident from both the literature review and our investigations that teaching staff who lag behind new largely digital native generations need to acquaint themselves with new technologies and approaches to ensure smooth and effective introduction of social media in HE. Also social media could provide opportunities for disadvantaged groups such as the disabled and dispersed people in rural communities to participate in education. We propose the following guidelines for this purpose:

1 Organisation of a social media strategy in teaching modules/courses: Teaching staff should discuss how e-learning on social media should be organised so that it supports learners' development in their studies. Our study showed that students appreciate that the meaning of IT infrastructure and social influence are highly important 
(Makkonen et al., 2015). The usability issues are also important. These should be looked at while creating social-media-based learning activities. In particular, we should take into consideration what tools make sense in the current education. The strategy should include these elements as well as the selection a right tool (or tools) for each teaching and learning context (Tsitsekidou, 2015). By canvassing their students in order to determine what social media tools they prefer to use in their leisure time, this knowledge can be used to advocate what social media tools to use in their respective learning environment.

2 Analysis of learning conditions of students: Because, as teaching staff, we are not aware of the conditions of infrastructure at students' homes, the learning conditions of learners should be analysed as the first step in developing new learning activities based on social media. Whitney et al. (2011) reported that many changes have been occurring in identifying vulnerable groups who are subject to social disadvantage as a consequence of age and disability as well as other factors such as low educational achievement, poverty and living in remote rural areas. These groups of people despite often living in developed countries usually with strong economies are not included or are not keeping pace with technological developments and opportunities. Thus, it is important that digitally excluded learners are not disadvantaged further by the introduction of social media in HE.

3 When an instructor is deciding what social media tools to use in teaching, it is vital that they take into consideration what learning aspect they attempting to focus on/assess. For example, if they are attempting to foster organisational skills in their students' learning, then the appropriate social media tools should be used, as suggested in Table 2. The learning aspect must be aligned with the most appropriate social media toll in order to gain maximum efficacy.

4 The quality and reliability of the social information used: Teaching staff need to instruct learners in their studies to be information literate. Information sourced, and used, via social media, and the internet may come to a learner in unfiltered formats, which elicits questions about the information's authenticity, validity and reliability. Thus, staff introducing social media in HE must, in addition, teach learners the ability to evaluate information, i.e. become information literate.

5 If an instructor is attempting, in a traditional classroom setting, to engender in their students learning the ability to unconscious learning, knowledge sharing and organisational skills, then our findings suggest that they could make effective use of social media, e.g. Facebook, which learners tend to see as tool that can invoke these highlighted abilities.

6 Consideration of the ethical and legal issues invoked by the use of social media in $H E$ : Teaching staff, alongside learners require a code of conduct that will explicitly state what is, or is not, acceptable ethical behaviour in the use of social media in HE. Such a code should cover issues such as online harassment/abuse; intellectual property, authenticity of participants, privacy, etc.

7 Security and service disruptions: Potential security risks involved in contributing content should be addressed. Risk management including contingency plans should be created for potential service disruption. 


\section{Conclusion and further work}

Our main study interpreted the meaning of the different aspects of the unified technology adoption model when applied to the adoption of social media in HE. Based on the UTAUT model, our results show that the first priority is the need to pay special attention to infrastructure of ICTs before implementing social media solutions. Another issue is that we are not aware of the conditions at home. Thus, the learning conditions of learners should be analysed as the first step in outlining new learning activities based on social media. The second most important factor is the selection of the best platforms in the light of usability. After this, an educator should discuss how e-learning on social media should be organised in order to support learners' development in their work and/or studies. We found that the students consider the social influence highly important.

The follow-up studies investigated what social media tools are preferred by students and if they have a positive impact on students' learning.

Finally, we investigated in more detail the use of a Facebook group and its impact to the students' learning process in terms of factors, such as students' engagement, students' motivation, students' collaborative learning and students' satisfaction. The results show that a Facebook group is a contemporary social media tool preferred by students for enhancing their learning. The study shows that Facebook groups support the collaboration between students and contribute positively to their learning process.

Based on our results, we also proposed guidelines for planning social-media-based learning activities.

In future, we are going to present further analyses of data from our studies and other similar studies we have carried out in order to build a complete picture of major success factors in social-media-based learning. In particular, we are interested in understanding what social media skills of teaching staff should be developed to run successful socialmedia-based learning courses. Ravenscroft et al. (2012, p.177) suggested that given the pace of change in the possible social media configurations, or 'digital ecosystems', that can be deployed in support of informal and formal learning, it is clear that we need to focus on a more future-proof concept than the technologies themselves, which will assist us in both better understanding and realizing learning, or new forms of learning.

In addition, we are going to apply the theoretical framework developed by the US Content Subcommittee of the Impact CS Steering Committee (Huff et.al., 1995) which specifies six moral and ethical concepts (quality of life; use of power; risks and reliability; property rights; privacy; and equity and access). In doing so, it will allow us to comprehensively identify the professional, social, legal and ethical issues invoked by the use of social media in HE. In turn, this insight can be used by both instructors and developers to develop and deploy ethical and legally sound learning materials, to be supported by social media.

\section{Acknowledgements}

We would like to thank students, teaching staff and researchers at both ATEI of Thessaloniki and Jyväskylä University for providing the Greek and Finnish data and for useful comments regarding the results of the survey. We would also like to thank Maria Tsitsekidou, postgraduate student from Alexander Technological Educational Institute of Thessaloniki for the follow-up data and valuable discussions of the results. 


\section{References}

Abedin, B. (2016) 'Diffusion of adoption of facebook for customer relationships in Australia: an exploratory study', Journal of Organisational and End User Computing, Vol. 28, No. 1, pp.56-67.

Ajzen, I. (1991) 'The theory of planned behavior', Organisational Behavior and Human Decision Processes, Vol. 50, pp.179-211.

Ajzen, I. and Fishbein, M. (1980) Understanding Attitudes and Predicting Social Behavior, Prentice-Hall, Englewood Cliffs, NJ.

Cachia, R. (2008) Social Computing: Study on the Use and Impact of Online Social Networking, IPTS Exploratory Research on the Socio-economic Impact of Social Computing, EUR 23565 EN, European Commission, Joint Research Centre, Institute for Prospective Technological Studies, Office for Official Publications of the European Communities, Luxembourg.

Dabbagh, N. and Kitsantas (2012) 'Personal learning environments, social media, and self-regulated learning: a natural formula for connecting formal and informal learning', Social Media in Higher Education, Vol. 15, No. 1, pp.3-8.

Dabbagh, N. and Reo, R. (2011) 'A transformative framework for social software use in E-learning', in Bastiaens, T. and Ebner, M. (Eds.): Proceedings of EdMedia: World Conference on Educational Media and Technology 2011. Association for the Advancement of Computing in Education (AACE), pp.1315-1320. Retrieved 4/3/2017 from https://www. learntechlib.org/p/38039

Daniel, J. (2012) Making Sense of MOOCs: Musings in a Maze of Myth, Paradox and Possibility. Journal of Interactive Media in Education, Available at: http://www.jime.open.ac.uk/jime/ article/viewArticle/2 012-18/html (access 10 September 2016).

Davis, F.D. (1989) 'Perceived usefulness, perceived ease of use, and user acceptance of information technologies', MIS Quarterly, Vol. 13, No. 3, pp.319-340.

Davis, F.D., Bagozzi, R.P. and Warshaw, P.R. (1989) 'User acceptance of computer Technology: a comparison of two theoretical models', Management Science, Vol. 35, No. 8, pp.982-1003.

Davis III, C.H., Deil-Amen, R., Rios-Aguilar, C., and Gonzalez-Canche, M.S. (2012) Social Media in Higher Education: A literature Review and Research Directions, published by the Center for the Study of Higher Education at the University of Arizona and Claremont Graduate University. Retrieved 4/3/2017 from https://works.bepress.com/hfdavis/2/

Deng, L. and Tavares, N. (2013) 'From Moodle to Facebook: exploring students' motivation and experiences in online communities', Computers \& Education, Vol. 68, pp.167-176.

Deng, L. and Yuen, A.H.K. (2011) 'Towards a framework for educational affordances of blogs', Computers \& Education, Vol. 56, pp.441-451.

Dubois, H. (2002) 'Harmonization of the European vaccination policy and the role TQM and reengineering could play', Quality Management in Health Care, Vol. 10, No. 2, pp.47-57.

Faraon, M., Cronquist, B. and Kaipainen, M. (2011) 'Social media affordances in net-based higher education', in Huai, H., Kommers, P., Zhang, J-P. and Isaías, P. (eds.): Proceedings of the IADIS International Conference on International Higher Education, IADIS Press, Shanghai, China, pp.27-37. Retrieved 4/3/2017 from http://sh.diva-portal.org/smash/record.jsf?pid= diva2\%3A463128\&dswid=-4169.

Fishbein, M. and Ajzen, I. (1975) Belief, Attitude, Intention, Behavior: An Introduction to Theory and Research, Addison-Wesley, Reading, MA.

Georgiadou, E., Makkonen, P, Siakas, E. and Siakas, K. (2014) 'Benefits and challenges of social media in learning: a cross-cultural study, E-learn', 2014-World Conference on E-Learning in Corporate, Government, Healthcare, and Higher Education, 27-30 October, New Orleans, LA, Vol. 2014, No. 1, pp.313-318.

Graham, M. (2014) 'Social media as a tool for increased student participation and engagement outside the classroom in higher education', Journal of Perspectives in Applied Academic Practice, Vol. 2, No. 3, pp.16-24. 
Grodecka, K., Wild, F. and Kieslinger, B. (2009) How to Use Social Software in Higher Education Handbook. iCamp Project. Retrieved from: http://www.icamp.eu/wp-content/uploads/2009/01/ icamp-handbook-web.pdf(retrieved 17 April 2015).

Grover, A. and Stewart, D.W. (2010) 'Defining interactive social media in an educational context', in Marovich, C.M., Stanaityte, J. (Eds.): Cutting Edge Social Media Approaches to Business Education: Teaching with LinkedIN, Facebook, Twitter, Second Life, and Blogs, Information Age Publishing, Charlotte, NC, pp.7-38.

Hrastinsk., S. and Aghaee, N. (2012) 'How are campus students using social media to support their studies? An explorative interview study', Education and Information Technologies, Vol. 17, No. 4, pp.451-464.

Huff, C., Anderson, R.E. and Little, J.C. (1995) 'Integrating the ethical and social context of computing into the CS curriculum. An Interim Report from the Content Subcommittee of the Impact CS Steering Committee', Proceedings of ETHICOMP 95: An International Conference on the Ethical Issues of Using IT, 28-30 March, Leicester, UK, Vol. 2, pp.1-19.

Junco, R. (2011) 'The relationship between frequency of Facebook use, participation in Facebook activities, and student engagement', Computers \& Education, Vol. 58, No. 1, pp.162-171.

Junco, R., Elavsky, M. and Heiberger, G. (2013) 'Putting Twitter to the test: assessing outcomes for student collaboration, engagement and success', British Journal or Educational Technology, Vol. 44, No. 2, pp.273-287.

Keesee, S.G. and Shepard, M. (2011) 'Perceived attributes predict course management system adopter status', Online Journal of Distance Learning Administration, Vol. 4, No. 1. Retrieved 4/3/2017 from https://www.learntechlib.org/p/52632.

Lau, R.W.H., Yen, N.Y., Li, F. and Wah, B. (2014) 'Recent development in multimedia e-learning technologies', World Wide Web, Vol. 17, No. 2, pp.189-198.

Makkonen, P., Georgiadou, E., Rahanu, H. and Siakas, K. (2015) 'What promotes the adoption of social media in the teaching of IS/ICT and what constrains it?: students' perspective', in Mackelprang, A. (Ed.): DSI 2015: Proceedings of the 46th Annual Meeting of the Decision Sciences Institute, Houston: Decision Sciences Institute, pp.1-7. Retrieved 25/11/2016 from http://www.decisionsciences.org/Portals/16/Proceedings/AM-2015//files/

Makkonen, P., Georgiadou, E., Rahanu, H. and Siakas, K. (2016) 'Adoption of social media in the teaching of IS/ICT: Comparing students to faculty members', in Chamblee, G. and Langub, L. (Eds.), SITE 2016: Proceedings of the 27th International conference of Society for Information Technology and Teacher Education, Chesapeake, VA: Association for the Advancement of Computing in Education (AACE), pp.2194-2200. Retrieved 25/11/2016 from https://www. learntechlib.org/p/171995.

Mathieson, K., Peacock, E. and Chin, W.W. (2001) 'Extending the technology acceptance model: the influence of perceived user resources', ACM SIGMIS Database, Vol. 32, No. 3, pp.86-112.

Meyer, K.A. (2014) 'Student engagement in online learning: what works and why', ASHE Higher Education Report, Vol. 40, No. 6, pp.1-114.

Minocha, S. and Kerawalla, L. (2011) 'University students' self-motivated blogging and development of study skills and research skills', in Lee, M.J.W. and McLoughlin, C. (Eds.): Web 2.0-Based e-Learning: Applying Social Informatics for Tertiary Teaching, IGI Global, Hershey, PA, pp.149-179.

Mooney, C. (2009) Online Social Networking, Gale Cengage Learning, Detroit, US.

Nysveen, H., Pedersen, P.E. and Thorbjornsen, H. (2005) 'Intentions to use mobile services: antecedents and cross-service comparisons', Journal of the Academy of Marketing Science, Vol. 33, No. 3, pp.330-346 (Free Press, New York).

Onkvisit, S. and Shaw, J.J. (1994) Consumer Behaviour: Strategy and Analysis, MacMillan College Publishing Company, New York.

Oradini, F. and Saunders, G. (2008) 'Social networking: Connecting students and staff', Association for Learning Technology News 13. Retrieved 5/3/2017 from http://citeseerx.ist.psu.edu/ viewdocdownload?doi=10.1.1.520.772 \&rep=rep1\&type=pdf 
Pallis, P., Zeinalipour-Yazti, D. and Dikaiakos, M.D. (2011) 'Online social networks: status and trends', in Vakali, A., Jain, L.C. (Eds.): New Directions in Web Data Management 1, SCI 331, pp.213-234, Springer-Verlag, Berlin Heidelberg.

Ractham, P. and Firpo, D. (2011) 'Using social networking technology to enhance learning in higher education: A case study using Facebook', In System Sciences (HICSS), 44th Hawaii International Conference, Published by IEEE 04/01/2011, pp.1-10.

Ravenscroft, A., Warburton, S., Hatzipanagos, S. and Conole, G. (2012) 'Designing and evaluating social media for learning', Shaping Social Networking into Social Learning?, Vol. 28, No. 3, pp.177-182.

Rodrigues, J.E. (2011) 'Social media use in higher education: key areas to consider for educator', MERLOT Journal of Online Learning and Teaching, Vol. 7, No. 4, pp.539-550.

Rogers, E.M. (2003) Diffusion of Innovations, 5th ed., Free Press, New York.

Schiffman, L.G. and Kanuk, L.L. (1994) Consumer Behavior, 5th ed., Prentice Hall International Editions, New Jersey.

Seaman, J. and Tinti-Kane, H. (2013) Social Media for Teaching and Learning, Pearson Learning Solutions Retrieved from: http://www.pearsonlearningsolutions.com/assets/downloads/reports/ social-media-for-teaching-and-learning-2013-report.pdf\#view=FitH,0 (retrieved 9 September 2016).

Siakas, K.V., Belidis, A. and Siakas, E. (2014) 'Social media marketing for improved branding and valorisation in small family businesses', International Conference on Contemporary Marketing Issues (ICCMI 2014), 18-20 June, Athens, Greece, pp.764-772 (ISBN: 978-960287-145-4).

Siakas, K.V., Gevorgyan, R. and Georgiadou, E. (2011) 'IT methods and techniques applied to educational quality enhancement', International Journal of Human Capital and Information Technology Professionals (IJHCITP), Vol. 2, No. 3, pp.79-90.

Siemens, G. (2005) 'Connectivism: a learning theory for the digital age', International Journal of Instructional Technology and Distance Learning, Vol. 2, No. 1, pp.3-10. Retrieved 24/9/2016 from the Journal's website: http://www.itdl.org/Journal/Jan_05/ article01.htm.

Statistics Finland. (2010) Social Media: Survey on the Use of Interactive Media and Social Networking Services (Sosiaalinen media: verkkomedian ja yhteisöpalvelujen käyttö). Retrieved from: http://www.stat.fi/til/sutivi/2010/sutivi_2010_2010-10-26_kat_003_fi.html (retrieved 12 September 2017).

Tsitsekidou, M. (2015) Social Networks in Higher Education, Master's Thesis, Alexander Technological Educational Institution of Thessaloniki, Department of Informatics, Postgraduate Programme 'Web-Intelligence'.

Venkatesh, V. and Davis, F.D. (2000) A theoretical extension of the technology acceptance model: four longitudinal field studies', Management Science, Vol. 46, No. 2, pp.186-204.

Venkatesh, V., Morris, M.G. and Davis, F.D. (2003) 'User acceptance of information technology: toward a unified view', MIS Quarterly, Vol. 27, No. 3, pp.425-478.

Vygotsky, L.S. (1978) Mind and Society, Harvard University Press, Cambridge, MA.

Welch, B. and Bonnan-White, J. (2012) 'Twittering to increase student engagement in the university classroom', Knowledge Management E-Learning: An International Journal, Vol. 4, No. 3, pp.325-345.

Whitney, G., Keith, S., Bühler, C.B. Hewer, S., Lhotska, L., Miesenberger, K., Sandnes, S., Frode E., Stephanidis, C. and Velasco, C.A. (2011) 'Twenty five years of training and education in ICT design for all and assistive technology, Technology and Disability, Vol. 23, No. 3, pp.163-170 (ISSN 1055-4181). 